\title{
The role of humor discourse in the construction of gender identity
}

\author{
ESTHER LINARES BERNABÉU \\ Investigadora en formación \\ Dpto. Filología Española, Lingüística General y Teoría de la Literatura \\ Universidad de Alicante \\ 03080 San Vicente del Raspeig (España) \\ E-mail: esther.linares@ua.es
}

\section{THE ROLE OF HUMOR DIS- COURSE IN THE CONSTRUC- TION OF GENDER IDENTITY}

ABSTRACT: This research examines the way in which gender identity is revealed in language practice and explores its theoretical and practical implications. More precisely, this article aims to explore some of the interesting ways in which female stand up comedians use different speech styles marked by gender to deconstruct their imposed gender roles and, hence, reconstruct their identity as a sort of resilient process. We argue that the gendered speech style in humorous discourse may be used regardless of the speaker's sex to reassert one's identity and break with the boundaries and constraints inflicted by society. In this sense, our purpose is to verify the hypothesis that planned humor discourse is the means comediennes use to perform unconventional gender identities and subvert the normative standards. For this aim, our study collects a corpus that comprised 15 monologues by seven famous north-American and British stand-ups such as Tina Fey, Amy Schumer, Sarah Silverman, Kris ten Shaal, Ellen DeGeneres or Bridget Christie. These monologues were transcribed and divided into humorous sequences, in order to examine the function of the different speech styles when using role-play and its relation with the humor styles proposed by Martin et al. (2003) They served to account the most prominent discursive features. The analysis of the ef fects achieved in relation to the construction and deconstruction of gender identity, as well as the study of the linguistic and paralinguistic elements used to trigger the comic effect has allowed us to prove tha the use of a certain gendered speech style in a humorous discourse can act as a sociopragmatic device not for breaking with sex roles stereotypes, but also for reinforcing and perpetuating some gender clichés.

KEY WORDS: humor; gender; stand-up comedy; discourse; performance.

SUMMARY: 1 . Introduction. 2. Humor: a gendered device. 3 . Methodology. 4. Results. 5. Conclusion.

\section{EL PAPEL DEL DISCURSO HU- MORÍSTICO EN LA CONS- TRUCCIÓN DE LA IDENTIDAD DE GÉNERO}

RESUMEN: La presente investigación analiza la forma en la que la identidad de género se refleja en el habla y explora sus implicaciones teóricas y prácticas. En concreto, el objetivo principal es explorar las distintas formas interesantes en las que las humoristas hacen uso del estilo de habla femenino y masculino, a travé del discurso directo, con el objeto de romper con los roles sexuales y subvertir las nociones heteronormativas de masculinidad y feminidad. Partimos de la hipótesis de que, en el discurso humorístico, el estilo de habla femenino y masculino se usan con independencia del sexo para conseguir unos determinados efectos cómicos y sociales. Con el objetivo de verificar tal conjetura, este estudio recoge un corpus de 15 monólogos humorísticos representados por cómicas estadounidenses y británicas como Tina Fey, Amy Schumer, Sarah Silverman, Kristen Shaal, Ellen DeGeneres or Bridget Christie. La transcripción y segmentación de dichas muestras nos ha permitido examinar la función de los estilos de habla en el discurso directo y su relación con los estilos humorísticos propuestos por Martin et al. (2003). El análisis de los efectos conseguidos en relación con la construcción y deconstrucción de la identidad de género, así como el estudio de los elementos lingüísticos y paralingüísticos empleados para desencadenar el efecto cómico, nos ha permitido comprobar que el uso de un estilo de habla marcado por una determinada identidad de género es un instrumento discursivo que puede implicar tanto la ruptura de determinados roles sexuales como el refuerzo de tópicos y estereotipos de género.

PALABRAS CLAVES: humor; género; monólogo; discurso directo; estilo de habla.

SUMARIO: 1. Introducción. 2. Humor: una herramienta para el género. 3. Metodología. 4. Resultados. 5. Conclusiones.

\section{LE ROLE DU DISCOURS HUMORISTIQUE PLANIFIE DANS LA CONSTRUCTION DE L'IDENTITE DE GENRE}

RÉSUMÉ: La présente investigation analys le rôle du discours humoristique planifie dans la construction de l'identité de genre. L'objectif principal est d'explorer les différentes façons dans lesquelles le humoristes espagnoles font usage du style de parole féminin et masculin, en se servan du discours direct, ayant pour but de cesse avec les rôles sexuels et de bouleverser le notions hétéronormatives de virilité et féminité. Nous partons du principe que: dans le discours humoristique, le style de parole féminin et masculin s'utilisent ave indépendance du sexe pour obtenir certain effets comiques et sociales. Avec le but de vérifier telle conjecture, cette étude a un corpus de 15 monologues humoristique représentés par sept comédiens américain et britanniques, tels que Tina Fey, Amy Schumer, Sarah Silverman, Kristen Shaal, Ellen DeGeneres ou Bridget Christie, dan des salles et des théâtres. La transcription et la segmentation de telles exposition nous ont permis d'examiner la fonction des différents styles de parole dans le discour direct et sa relation avec les style humoristiques proposés par Martin et al. (2003). L'analyse des effets obtenus en rapport avec la construction et déconstruction de l'identité de genre, ainsi que l'étude des éléments linguistiques et paralinguistiques employés pour entraîner l'effet comique, nous ont donné la possibilité de confirmer que l'usage d'un style de parole influencé par une certain identité de genre est un recours discursif qui peut impliquer aussi bien la rupture de certains rôles sexuels que la stimulation des clichés et des stéréotypes de genre.

MOTS CLÉS: humour; genre. stand-up comedy; discours; représentation.

SOMMAIRE: 1. Introduction 2. Humour : un dispositif de genre 3. Méthodologie 4. Résultats 5. Conclusion $\begin{array}{ll}\text { Fecha de Recepción } & 19 / 09 / 2018 \\ \text { Fecha de Revisión } & 29 / 10 / 2019 \\ \text { Fecha de Aceptación } & 02 / 11 / 2019 \\ \text { Fecha de Publicación } & 01 / 12 / 2019\end{array}$ 


\title{
The role of humor discourse in the construction of gender identity ${ }^{1}$
}

\author{
ESTHER LINARES BERNABÉU
}

\section{INTRODUCTION}

Humor is an interdisciplinary occurrence that has been study for centuries from a great variety of perspectives. Linguists, who have centered their studies on verbal humor, define it as a pragmatic phenomenon based on an incongruity, which needs to be solved in order to trigger a comic effect. To this end, the reader/listener activates certain inferences, which help interpret the humorous message (Raskin, 1985; Attardo, 1994; Ruiz Gurillo, 2012).

Undoubtedly, the main aim of is to amuse and activate mirth on us. Nevertheless, it can also function as a coping tool, which humorists may use to create an alternative perspective and even alter power normative structures (Russell, 2002: 8; Willis, 2003). In this respect, if we focus our attention on the different functions performed humor may have, we could argue that one of these could be to defy stablished normative gender identities, as we will try to verify in this article. Accordingly, we will analyze seven well-known stand-up female comedians: Tina Fey, Amy Schumer, Sarah Silverman, Kristen Shaal, Ellen DeGeneres, Bridget Christie and Iliza Shlesinger. These north-American and British comedians employ humor as a tool to empower themselves on stage and challenge the status quo.

Our main purpose will be to examine the way language is used in humorous planned discourses and the effects it achieves, both comical and social. As an initial hypothesis, we state that female comedians are aware of their capacity to manipulate and shape their gender identity through their speech style and the use of different humor markers. Additionally, as a second general hypothesis, we argue humor may be a sociopragmatic tool employed by the comedian in her conscious motivation for shaping her gender identity on stage and going beyond boundaries.

Regrettably, the ways in which comedians collaboratively co-construct gender ${ }^{2}$ in spoken discourse, like stand-up comedy, is yet to be fully explored. Thus, using insights from the cognitive linguistics theory of humor, our research tries to provide an explanation on how inferences are made between what stand-ups say and what they intend to convey. Moreover, research has mostly ignored the context-dependence nature of construct concepts, such as gender identity, and their expression and functions within

\footnotetext{
${ }^{1}$ This research was supported by the Valencian Regional Department of Education, Research, Culture and Sport by means of the grant PROMETEO/2016/052 "Gender-based humor: Observatory of identity of women and men through humor".

${ }^{2}$ All the studies about gender co-construction have been taken in conversational humor (Crawford, 2003; Coates, 1999, 2014)
} 
different genres and discourses. In this sense, we aim to show how humor language in planned discourse, as it is stand-up comedy, leads to the reinforcement of pre-established concepts of gender roles and to the subversion of stereotypical ideas regarding gender identity.

In short, this paper aims to show how the concept of gender emerges and is constructed and deconstructed in different ways by multiple female humorists in spoken planned discourse, like stand-up comedy. We will also examine how humor, in this type of discourse, is a resource for building gender identity in interaction with the audience, and how it can serve a variety of functions, such as persuading, entertaining and raising awareness.

Consequently, in order to fulfill our goals, the following is an examination of the main theories on language and gender and its connection with humor discourse. In particular, we will follow the cognitive linguistics theory of humor as it is the one that better adapts to our research needs (chapter two). Then, in chapter three I move on to present the methodology and the main characteristics of my corpus. Chapter four seeks to examine and discuss our findings in order to verify our hypothesis. Finally, chapter five will provide conclusive thoughts and suggest future lines for research on this field.

\section{HUMOR: A GENDERED DEVICE}

The relationship between gender and humor has been widely studied from different disciplines, such as anthropology, psychology, sociology, ethnography, education or linguistics. Indeed, there is an undeniable bourgeoning interest in humor discourse from a gender perspective and research in this issue has brought out fascinating outcomes (Lockyer, 2011; Chiaro and Baccolini, 2014; Ruiz Gurillo, 2019a). However, despite the developing literature on language and gender, the strategies comediennes use in their discourse to perform gender are still almost unexplored. Thus, in order to fill in this gap, the aim of this paper is to produce insightful analysis on the shaping of gender identity through humor language. From a sociolinguistic and pragmatic approach, we will focus on the linguistic strategies female humorists employ to either disrupt or maintain gender sex roles in their humorous performative discourses.

According to Holmes and Marra (2010:10): language plays an important part in constructing the gender order. In different social contexts, and even at different points within the same interaction, participants emphasize specific facets of their social identities and dimensions of social meaning, including their gender identity and gendered meanings (Cameron 2009; Eckert and McConnell-Ginet 2003; Meyerhoff 1996; Meyerhoff and Niedzielski 1994). In this regard, we will follow the social constructionist and performative approach proposed by Butler (1990), which highlights the varied, flexible, and context-responsive ways in which people 'do gender'. Accordingly, this research conceptualizes gender as a social dynamic performative construct that female comedians shape in a humorous context. 
However, until not long ago, the sense of humor was thought to be a personal trait that only men had. In fact, this thought gained consistency when in 1975 the linguist Robin Lakoff wrote her book Language and women's place and stated that women lacked sense of humor and that we were only the passive counterpart who were to laugh men's jokes. Empirical research has refuted this claim and it has been proved that we are not humorless but that we appreciate and perform humor in a different form and for different purposes (Jenkins, 1985; Crawford, 1991; Coates, 2007). Interestingly, it has been shown that humor reception and production is affected by different factors such as age, ethnicity or gender (Crawford, 2003; Martin, 2007; Timofeeva, 2014). In this study, we will focus on gender, as it is a key factor in humor discourse. On this point, Chiaro \& Baccolinni (2014) state that:

Gender conditions the most minute details of our lives, possibly more than our age, our social background, and our ethnicity, and, thus, it stands to reason that the way we "do" humor may also, in some way, be accordingly gendered.

\subsection{CONSTRUCTING THE CONCEPT OF GENDER THROUGH SPEECH}

Without a shadow of a doubt, humor is a cognitive phenomenon, and verbal humor a cognitive-pragmatic one which is based on the creation and resolution of an incongruity produced by two frames in a particular context (Veale, et al., 2006). One of the main interests of Cognitive linguistics has been figurative language, as it is the means we use for stating one idea in terms of another. Humor language is made of linguistic elements, known as markers, which contribute to figurativeness in speech such as metaphor, polysemy, or phraseology (Ruiz Gurillo, 2014). Consequently, we have considered reasonable to follow a cognitive linguistic approach for this study, and by using Langacker's (2001) model of meaning construction in discourse, we aim to examine how the concept of gender can be constructed, deconstructed, and even co-constructed through humor in planned discourse. Humorists decide which aspects of their gender want to emphasize and make more salient to achieve their humorous and communicative goals, being these either reinforcing the normative feminine identity or challenging the prejudices and clichés (Yus, 2016; Linares Bernabéu, 2020). In this sense, the comedian guides the audience from a first conception of their idea of gender to the one she really wants to show through the humorous sequence. This idea would follow Veale, et al. (2006) postulations:

The fact that profiled aspects of a structure will appear more salient than others allows linguistically-creative people to achieve humorous misdirection, causing observers to focus on the profile (or figure) while the essence of the joke goes unmarked in the base structure (or ground). 
Furthermore, Langacker's notion of discourse space will be central for our study, which he defines as the mental space that comprises the elements and relations shared by the speaker and the hearer as a basis for communication in a given context during the flow of discourse (Langacker, 2001:144). Thus, we maintain that the meaning of gender resides in the tension between the gender aspects that are being profiled and its conceptual base, where all other contextual elements may be evoked as relevant structures of the base. In general terms, following Langacker's ideas, concepts are argued to be structured around a prototypical center, with specific instantiations being more or less representative of that concept, depending on the position they take up vis-à-vis the prototype. Accordingly, the concept of gender identity would have, as a prototypical center, a binary distinction of gender, which, in turn, is filled with stereotypes and gender roles. This prototype would be challenged by the instantiations of gender that standups perform on the stage.

Therefore, salience plays a crucial role in negotiating meaning, as it is the agents' duty to attribute the specific levels of prominence to the concept, for it to have a certain word reading (Giora, 2003). Consequently, inferences, conventionality and context, as well as expectations and mind-set of the agent, are aspects to consider when analyzing the construct operations of a concept like gender identity.

\subsection{THE PERFORMANCE OF GENDER IN HUMOR DISCOURSE}

There has been large academic research in gendered talk since the 1970s, and it seems inevitable to mention Lakoff work as the primogenitor on this field. In her work Language and women's place, Lakoff (1975) claimed that the differences in language use reflected women's lack of power. The deficit theory helped her explain why we use more question tags, hedges and a hypercorrect grammar. On the one hand, it was a highly controversial work as it lacked empirical data for supporting her findings. However, on the other hand, this work also constituted the beginning of research on gendered discourse and linguistics. Following the dominance theory, others like Spender or Fishman have suggested that we use language in a different way because our upbringing has been different, and we have been socialized differently (Maltz and Borker, 1982: 196). Then, since the 1990s scholars such as Deborah Tannen and Jennifer Coates have written extensively on the gender differences in discourse. Tannen (1992: 24) explains why women show closeness and rapport in their talk while men are more competitive and spirited in conversation. Furthermore, in agreement with Tannen, Cameron (1990: 26) corroborates that there is more mutual support and less need for individual self-assertion in women talk. Likewise, Coates (1993: 139) argued that the differences in language use stem for the patriarchal structure the world is organized in. 
However, all these theories about the links between gender and language pose the binary distinction of sexes to analyze gender in discourse, which may narrow the scope of our study. According to Stokoe and Smithson (2001), these essentialist theories foster a dichotomy which may bias any study of language and gender.

This research follows a social constructionist approach according to which gender is seen as a dynamic, socially constructed phenomenon we perform through discourse. In other words, people make use of linguistic resources in order to perform their gender identity (Crawford, 1995). In fact, we approach gender from the constructionist theory defended by Butler (1990, 1993). According to Butler, gender is something one does and not something one has. We all perform gender and it is constructed throughout our daily practices and attitudes, independently of our biological sex. She is also quite critical with the binary division literature has tended to make when analyzing gender as a category dependent on sex. Regarding our area of study, linguists such as Cameron or Chiaro have also decided to support this philosophical theory. For instance, Cameron (1995) claims that:

If I talk like a woman this is not just the inevitable of the fact that I am a woman; it is one way I have of becoming a woman, producing myself as one. There is no such thing as "being a woman" outside the various practices that define womanhood for my culture -practices ranging from the sort of work I do to my sexual preferences to the clothes I wear to the way I use language.

Cameron (1995: 46)

In the last decades, there has been a rise in theoretical research that shows how social categories, like gender, are negotiated through linguistic practice, what implies that they are not fixed, but shifting and variable constructs (Hay, 2001). On this matter, we would argue that humor language may contribute to the dynamic performance of gender identity on the stage. Following the GRIALE research group nomenclature, humor language is made of indicators, which stands for the lexical, syntactical and phonetical resources, and markers, that is to say, all the prosodic, paralinguistic, kinetic and typographic elements that help the comedians reach their humorous goals and perform their gender identity (Ruiz Gurillo, 2012: 78-86).

There is no doubt that gender is a social category with an ever-present influence on our behavior. According to Holmes and Schnurr (2014:166), we are always aware of the gender of our interlocutors, and, unconsciously, we tend to act according to the gendered norms and stereotypes that society has imposed.

\subsection{IS SPEECH STYLE AN ECHO OF A TRAIT OF GENDER IDENTITY?}

Furthermore, this paper also follows Gal (1995: 170-1) and Cameron (1997: 43) ideas about the speech styles interwoven with gender identity. According to these scholars, feminine and masculine speech styles have 
nothing to do with the speaker's sex. In fact, these speech styles ${ }^{3}$ which link to the notion of masculinity and femininity stem from the western society cultural norms and stereotypes. Gender identity is a dynamic category that we construct in our utterances; in other words, there is not any given identity, but we as individuals choose what traits from our gender want to display in our speech (Ochs, 1992). Accordingly, gendered speaking styles exist independently of the speaker, and the subjects decide which to use depending on the communicative effect they want to achieve. In consequence, female comedians may adopt male speech practices and use certain paralinguistic features associated with "men talk" for their comic purposes, while performing an alternative gender identity, which break with the patriarchal norms (Linares Bernabéu, 2020).

After these theoretical considerations, we have set as an initial hypothesis that the effect of this type of humorous discourse may be twofold. On the one hand, it may help break with the clichés and gender stereotypes stablished by patriarchy but, on the other hand, it may also contribute to reinforce some the heteronormative system and the differences between sexes. Our view is supported by previous research undertaken by Yus (2002, 2016), who presents a taxonomy of humorous consequences regarding reinforcement or subversion of sex roles. According to Yus (2002), stand-up comedians, consciously or not, use their discourse to produce an effect on the audience. They can show an uproarious attitude towards female cultural representation and, therefore, they use their speech to show their disagreement and challenge the status quo, or, on the contrary, sometimes they simply raise awareness about some social injustices such as gender gap pay or poor maternity conditions but do not go forward with their claim.

\subsection{FUNCTIONS OF DISCOURSE IN STAND-UP COMEDY}

Stand-up comedy, as a type of planned humorous discourse, both resists and conforms to societal expectations of women. Comedy is not always necessarily critical as it can also reinforce the status quo and function as a conservative tool or even as an exclusionary mechanism in the service of hierarchical power relations (Ruiz Gurillo, 2019b). Indeed, gender hierarchies and sex roles are sometimes preserved and reproduced through discourse practices (Yus, 2002; Russell, 2002).

On the other hand, humor is a great tool to critique topics which would be otherwise socially inappropriate to bring up. It is undeniable that comedians are able to speak out defiantly without being heavily reprimanded. According to Bianco (2015): "with a dose of humor, even the most bitter medicine tastes sweet; comedy can make feminism more palatable and accessible to the general public". This idea was also previously shares by Gilbert (2004: xxi)

\footnotetext{
${ }^{3}$ According to Stokoe and Smithson (2001: 245) these type of discourses can be described and analyzed because of our cultural background knowledge.
} 
Within the topsy-turvy word of stand-up comic performance, hierarchies are inverted, power relations are subverted, and a good time is had by all. Because it can avoid inflaming audiences by framing incisive - even incendiary - sociocultural critique as mere 'entertainment', comedy is undeniably a unique and powerful form of communication.

Through this paper we will see how humor mirrors social reality, exposing inequalities and creating alternative perspectives. Accordingly, we argue that female stand-up comedy serves to reassert one's identity and break with all those boundaries and constraints imposed by society. In this regard, female stand-ups could then be seen as a sort of activists who use comedy for their campaign against gender inequalities and injustices.

\section{Methodology}

\subsection{ANALYTIC METHODOLOGIES}

In this study, we have examined a particular data excerpt following the perspective of the cognitive linguistics theory of humor, the GRIALE humor language model, conversation analysis (CA) and two other critical methodologies commonly used by feminist language researchers, namely critical discourse analysis (CDA) and sociocultural linguistics/interactional sociolinguistics (IS), in order to facilitate a wide analysis.

On the one hand, CA is well placed to transcribe in fine detail the many changes of prosody associated with different voicings (pausing, intonation, stress, pitch) - as seen in the transcript. This type of analysis can strengthen empirical work by pointing to micro-structures in the monologue (e.g. selfinterruption) that dovetail with a macro analysis. Besides, through CDA we can focus on the place of context and power in understanding and analyzing data of this kind. Then, on the other hand, this analysis acknowledges the importance not just of polyphony, but heteroglossia, that is making visible the relatively powerless voices (Baxter 2003). We will take a particular interest in how participants may enact multiple subject positions, thereby shifting in their states of powerfulness/ powerlessness throughout their discourse. adopt discourse styles and strategies which have been normatively associated with masculinity or femininity (Holmes 2006, Mullany 2007).

\subsection{Participants}

We provide an in-depth discourse and conversational analysis of a corpus which comprised 15 monologues by seven famous north-American and British stand-ups such as Tina Fey, Amy Schumer, Sarah Silverman, Kristen Shaal, Ellen DeGeneres or Bridget Christie. This paper focuses on female comedians, as they have been the ones who less attention have received in academia because of the permanent skepticism and prejudices about women's comedic abilities. The widespread thought of women not being 
funny has still present in today's world, and hence Stand Up comedy is a sector dominated by men. According to Russell (2002:2), male comics are assumed to be funny until the show the contrary whereas their female counterparts must win the audience over by demonstrating that they are also humorous.

\subsection{DATA}

The monologues are drawn from live televised shows available on Netflix, and videos recorded on live shows at different theatres and bars which can be accessed on YouTube. We entirely agree with Schegloff's opinion that if we want to undertake a sociolinguistic analysis on the variable of gender in discourse, such factor must be relevant in the participants (Schegloff 1992: 192). But, what counts as gender relevance? For CA, the fact that speakers are men or are women is not sufficient warrant for analyzing what they say as 'gendered' (Schegloff, 1997). One proposal regarding gender relevance has been to point to the actual use of gender terms or to where clear gender relevant categorical inferences are being made (Stokoe, 2008). However, not all references to gender are used by participants to make gender relevant (e.g. the routine use of gender pronouns). In addition, gender/sexuality can be relevant when explicit reference to gender is not made (Kitzinger, 2007).

Consequently, we have focused on instances in which their maleness or femaleness seem to be oriented to as relevant. In all the monologues, the gender identity of the speakers shapes their speech. Thus, we have selected 15 monologues from seven female stand-up comedians. In all the examples selected, gender is salient, and this was reflected because of the topics, the language used and the style. Our corpus has a length of 430 minutes and 12 seconds and, in order to make our qualitative analysis more comparable and unbiased, we transcribed each show according to the Val.Es.Co system and divided them into humorous sequences, which could be defined as a series of interventions, interrupted by the public's applause and laughter, which deal with a certain topic. This segmentation has made a total of 107 sequences.

In particular, we have collected examples from comedy shows from the last nine years (2010-today) and examined how language helps to perform gender on the stage. The following table summarizes the main information of our database:

\begin{tabular}{|l|l|l|}
\hline Comedian & Monologue & Source \\
\hline Tina Fey & $\begin{array}{l}\text { How Tina Fey } \\
\text { copes with }\end{array}$ & $\begin{array}{l}\text { https://www.cnn.com/videos/cnnmoney/2017/08/18/fal- } \\
\text { Char- } \\
\text { lottesville } \\
\text { rally } \\
\text { Stand for-meyers-fey-weekend-update-charlottesville-jnd-orig- } \\
\text { rights } \\
\text { righ.cnn }\end{array}$ \\
\hline
\end{tabular}




\begin{tabular}{|c|c|c|}
\hline $\begin{array}{l}\text { Ellen De- } \\
\text { Generes }\end{array}$ & $\begin{array}{l}\text { Fitch please } \\
\text { I have a rest- } \\
\text { less leg syn- } \\
\text { drome } \\
\text { Helping peo- } \\
\text { ple is so } \\
\text { much better }\end{array}$ & $\begin{array}{l}\text { https:/ / www.youtube.com/watch?v=5VRJRy9rnfE } \\
\text { https:/ / www.youtube.com/watch?time_con- } \\
\text { tinue=33\&v=rNiR947LVVM } \\
\text { https:/ / www.youtube.com/watch?v=AqX0njD15k8 }\end{array}$ \\
\hline $\begin{array}{l}\text { Amy } \\
\text { Schumer }\end{array}$ & $\begin{array}{l}\text { Leather spe- } \\
\text { cial }\end{array}$ & $\begin{array}{l}\text { https: / / www.net- } \\
\text { flix.com/watch/80150002?trackId=14170034\&tctx=6\%2C2 } \\
\text { 5\%2C20f8c8e6-e93d-49e0-82ad-4fb526403d06-1226851 }\end{array}$ \\
\hline $\begin{array}{l}\text { Sarah Sil- } \\
\text { verman }\end{array}$ & $\begin{array}{l}\text { A speck of } \\
\text { dust }\end{array}$ & https://www.netflix.com/title/80133554 \\
\hline $\begin{array}{l}\text { Kristen } \\
\text { Shaal }\end{array}$ & $\begin{array}{l}\text { The tainto- } \\
\text { logue mono- } \\
\text { logue }\end{array}$ & $\begin{array}{l}\text { http:/ / www.cc.com/video-clips/eulphs/stand-up-kristen- } \\
\text { schaal--the-taintologues-pt--1 }\end{array}$ \\
\hline $\begin{array}{l}\text { Iliza Shle- } \\
\text { singer }\end{array}$ & Freezing hot & https://www.youtube.com/watch?v=EralV69aVs8 \\
\hline $\begin{array}{l}\text { Bridget } \\
\text { Christie }\end{array}$ & $\begin{array}{l}\text { Stand up for } \\
\text { her }\end{array}$ & https://www.netflix.com/title/80179907 \\
\hline
\end{tabular}

\section{Results}

In this section, we will examine the impact of verbal humor in the construction and deconstruction of gender and how it affects to the resistance and reinforcement of gender normative identities. Humor language serves to reassert one's identity and break with the boundaries and constraints imposed by society. Indeed, humor has become an incisive tool against patriarchy and misogyny. Comedians like Tina Fey, Amy Poehler, Ellen DeGeneres, Kristen Schaal, Bridget Christie, Sarah Silverman, or Amy Schumer mock at feminine stereotypes and the ideas of masculinity. Besides, it is also worth noticing that these humorous sequences produce a twofold effect: they break with the status quo and they create a new vision of what is meant by femininity and masculinity.

\subsection{DECONSTRUCTING THE NORMATIVE GENDER IDENTITY}

Irony and satire are key elements of this type of discourse as it helps the comedian to distance herself from the echo and to show her dissent with societal issues such as the normative femininity, in order to raise awareness in the audience and criticize the established social norms. This humorous sequence from Sarah Silverman's monologue is a good example of that.

Example 1

Silverman: we give our daughters Barbie dolls so that they have an image of what they should look like when they grow up/ that is not attainable so that they can learn that they're a piece of shit and they should kill themselves

Audience: [LAUGHTER]

Silverman: [it's so important] 


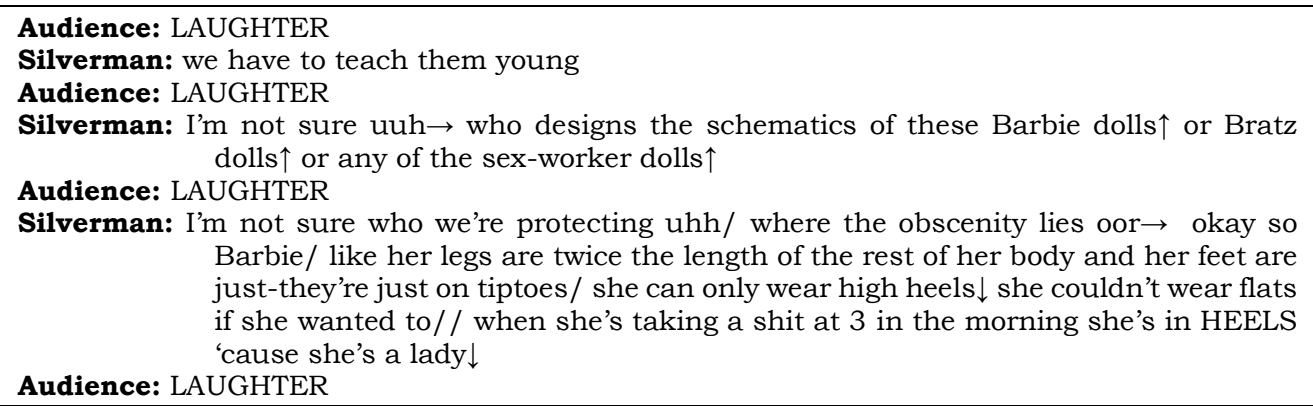

Interestingly, male speech style had always been related to power (Cameron, 1997), but here the female comedian uses the masculine voice to parody it in order to undermine the presumed supremacy men have. Furthermore, while doing this, she is going beyond gender boundaries and creating new meanings of femininity. In fact, the prototypical center for the concept of the feminine gender identity is fist filled with stereotypes such as the one of Barbie doll and the use of heels and then it is challenged in the punch line of the sequence when Silverman breaks with a scatological taboo.

In the next example from Schumer's monologue, the comedian deals with one of the most common topics in this type of discourse: sex. In this case, we can observe how by mimicking male speech and mocking traditional discourses of heteronormative female talk, Amy Schumer overthrows the stereotypes of female subordination. In addition to this, when the comedian speaks as a lady-like, she makes use of different prosodic markers such as intonation and high pitch, paralinguistic features like speaking softly and non-verbal resources like feminine manners, smiling and nodding in order to mock that stereotypical behavior. Then, conversely, she performs masculinity by shifting the speech style. These shifts in Schumer's voice are seen as a sonic-crossdressing (Halberstam, 1998; Rodger, 2004: 20) that produces an incongruity in the listener's mind and promotes an ambiguous resolution that makes the audience laugh. This may show that gender, like anything else, can be changed and renegotiated.

Example 2

Schumer: they're thinking that/ and I'm over here like ooh should I get highlights? like $\rightarrow$

Audience: LAUGHTER

Schumer: he doesn't CARE

Audience: LAUGHTER

Schumer: he doesn't care

Audience: CHEERING AND LAUGHTER

Schumer: honey do you like my new nail color? It's ballet slipper// I would fuck you if Audience: LAUGHTER your head was a ballet slipper/ I don't caare

Schumer: we work so hard/ and they don't fucking care $\uparrow$ / isn't that a relaxing thought? 
Further, it could be argued that their comedy is not man-hating at all, as they don't show women as a better race, what they do is to show some of the man liabilities so as to diminish his power in the patriarchal structure. This would be the case of the second example, as Schumer uses role-play to parody the importance that men give to sex and women to physical appearance.

We have also noticed that comedians laugh at their own expenses and self-deprecating jokes work well in this kind of monologues. In this type pf discourse, self-deprecating humor works as a social group boundary strategy with the female sector of the audience, it serves to protect the positive face of the speaker, and it also helps the comedians prevent the others from laughing at their flaws, and by doing so, they turn them into strengths. Overall, humor is power, and a sense of humor about yourself means that you know your weaknesses and have overcome them.

This would be the case of example three, in which the comedian makes fun of women and places certain stereotypes in the center of the figure to break with them later on with information from the ground.

Example 3

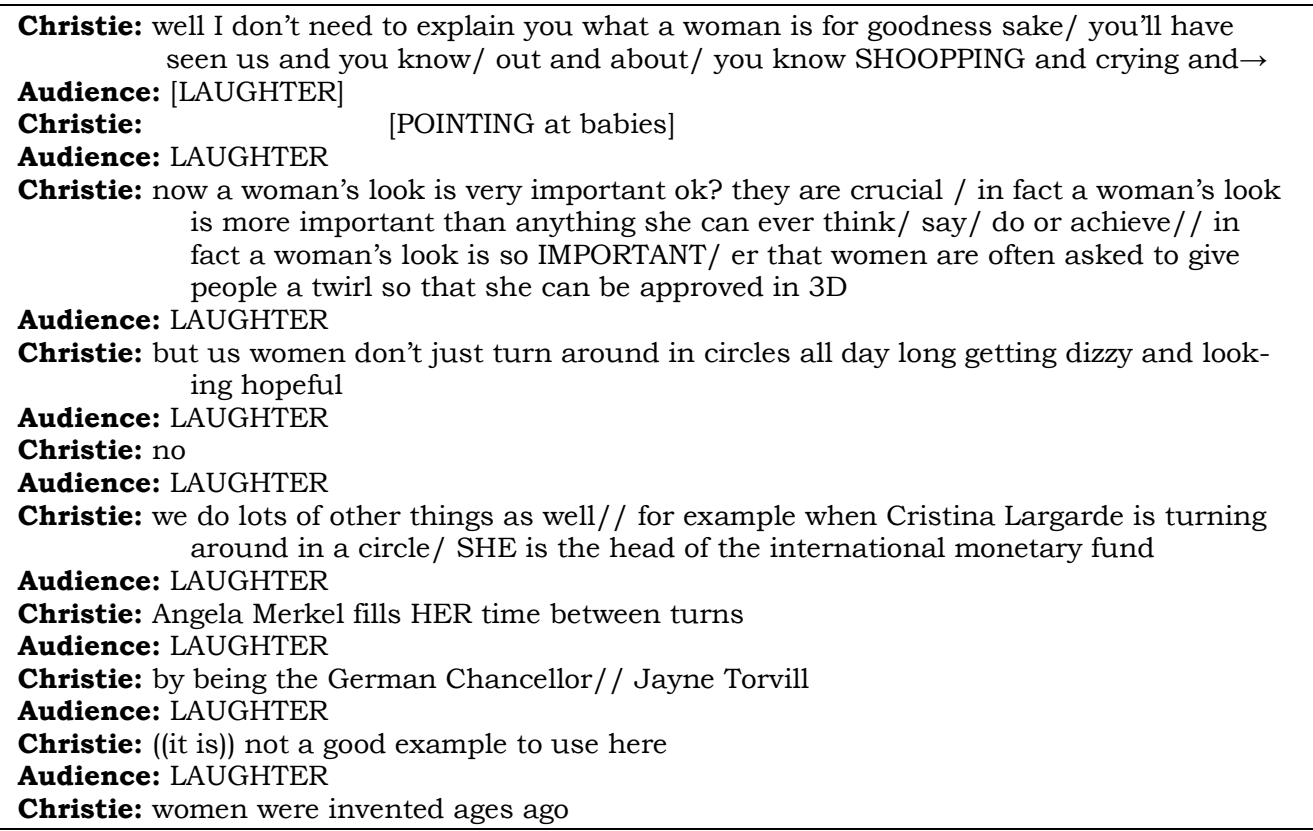

While enouncing the utterances, Christie expresses an attitude of dissociation with what she says. In fact, most of the laughter and applause come when the comedian conveys the message successfully, which means that the audience was able to infer the incongruity and the intention and attitude of the speaker. 
This adversarial humor style, in which the hearer infers the difference between what is said and what the comedian intends to transmit, is even more visible when it comes to trumpism. For instance, we see that Ellen DeGeneres challenges what it means to be a married lesbian, childless woman in today's actual society, and hence she confronts this taboo topic and deconstructs the identity it was imposed by the patriarchal society and reconstructs an alternative one.

Example 4

DeGeneres: you know/ I've told you this before $\rightarrow$ I don't usually read anything about myself/ I don't look at the tabloids or the Internet unless it's about me

Audience: [LAUGHTER] being pregnant

DeGeneres:

[then how else would I know/ we got to find out]

DeGeneres: Uh but I heard there was an article written about me and I would like to address it right now/ it's a pastor who wrote an article for The Christian Post where he accuses Hollywood of having a gay agenda/ and said that Ellen DeGeneres celebrates her lesbianism and "marriage" in

Audience: LAUGHTER between appearances of guests like Taylor Swift to attract young girls

DeGeneres: okay/ let's just break this down $\downarrow$ first of all, I'm not married/ I'm married $\downarrow$ that's all

Audience: CHEERS

DeGeneres: and Lar-Larry/ I don't even know what it means to celebrate my lesbian-

Audience: CHEERS ism/ I mean well I guess I do /it's like that ${ }^{4}$

DeGeneres: [I'm gay $\uparrow]$

Audience: [APPLAUSE]

DeGeneres: so in the article, the pastor criticizes a lot of TV shows for promoting gay agendas/ he says that Glee has over five characters $\uparrow$ Modern Family had a gay wedding $\uparrow$ Anderson Cooper boasts about his homosexual-

Audience: LAUGHTER ity $\rightarrow$ if you ask me/ Larry is watching a lot of gay TV

The previous example shows the way the female monologist uses a more sophisticated understanding of the concept to be married to both agree with the speaker (the priest) and simultaneously subvert and overcome the speaker's intention to insult her. As we have been seeing, gender expectations are destabilized by women's comedic performance. In this case, DeGeneres strongly criticizes gender double standards as in gay marriage. Indeed, we can see in the next example how conventional definitions of "femininity" and "lady-like" role are subverted through the humor indicators and markers in their speech. According to Holmes and King (2017), the use of authoritative, direct and stereotypically masculine style is a humor strategy for the banter over men. Furthermore, her body language along with her tone challenge the constraints of lady-like stereotypes. This verifies Glass (1993) idea that gendered speaking styles exist independently of the

\footnotetext{
${ }^{4}$ She throws confetti
} 
speaker, and the subjects decide which to use depending on the communicative effect they want to achieve.

Example 5

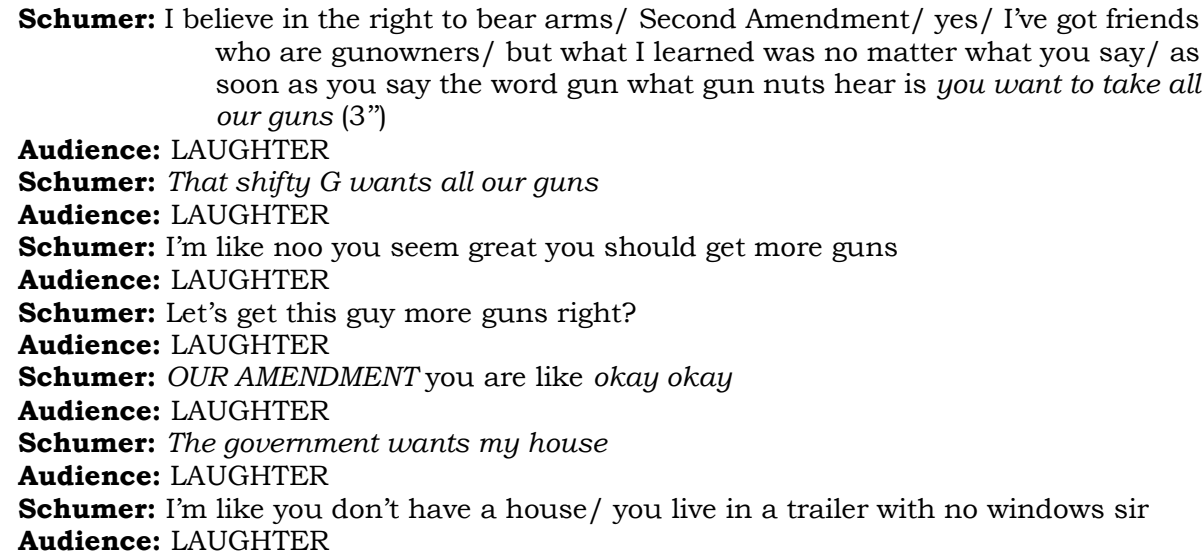

Humor is an effective strategy for deconstructing the roles imposed by society. Schumer's speech style de-automatizes and subverts habitual patterns of female speech, and this makes evident a sudden manipulation of the CDS via skillful parody of the adversary's own conceptual and linguistic construal of (male ${ }^{9}$ gun owners. Their discourse is full of intentional hyperboles that contribute to the creation of an incongruous script and to break with the femininity patterns. In this case, Ellen DeGeneres attributes male symptoms to a female friend, prostate, creating a cross-sex ambiguity which leads to laughter. However, it would be wrong to say they are acting in an anti-feminine way, but what they are doing is to construct other meanings for the notion of femininity through their discourse.

Example 6

DeGeneres: I think it's dangerous / because you know you don't know you might have
a headache or you feel tired and the next thing you know you have
convinced yourself you have asthma or you are pregnant with twins
Audience: [LAUGHTER]
DeGeneres:
Audience: LAUGHTER
DeGeneres: I had a friend call me/ her name is $\rightarrow$ well let's call her Nicole
Audience: [LAUGHTER]
DeGeneres: [that's her name]
Audience: LAUGHTER
DeGeneres: and so Nicole calls me and she says that she is having sharp pain $\downarrow$ so she
is online and she is reading one article that led her to another article
that led her to another article $\rightarrow$ about and hour later she was certain
that she had an enlarged prostate
Audience: [LAUGHTER]
De Generes:


Audience: LAUGHTER

DeGeneres: I was like $\rightarrow$ no Nicole/ no no// then she called me back/ it turned out she was sitting some marbles.

Audience: LAUGHTER

\subsection{SHOWING AN EMPOWERING STYLE}

In our view, the exaggerated sexuality and vulgarity from females in stand-up comedy can be considered a feature of their empowering style. Certainly, the hyperbole is one of the indicators most used in these monologues. This element contributes to depict a belligerent stage persona with a non-normative gender identity. For instance, we see Schumer protesting the sexist double standard of not being able to say "pussy" on television, or how Kristen Schaal defends her reproductive organs. In both cases, we appreciate a push in gender hegemonic boundaries as well as the dynamic and context-responsive way in which humourists do gender when the audience responds to her jab lines positively.

\section{Example 7}

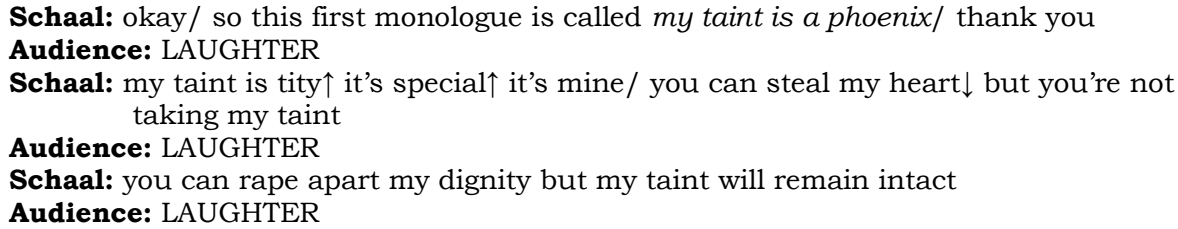

Our data shows how all the female comedians analyzed are able to insert serious statements within their monologues while making them sound thoughtful and hilarious at the same time. Indeed, the audience laughs because of how ridiculous and incongruent these true facts are. In this sense, Mintz (1985) argues that the reference to taboos and the deviant topics in Stand-Up comedy is one of the factors that triggers laughter and applauses in the audience. Most of them comment on their observations of sexism in the world, and refer to issues such as the tampon tax, public breast feeding, marriage, childbirth and the gender pay gap. In this example, Tina Fey, who is both writer and performer, makes people laugh, while making a point. She shifts from a serious message to an incongruent statement which, along with the audience laughter and applause, produces a humorous sequence. Indeed, she operated at the level of turn construction with her audience, and we can see how by producing a syntactically fitted but pragmatically subversive extension to at least part of her prior turn, she generates an incongruity that is treated as humorous (Veale, et al., 2006: 311). However, it is also arguable that in these type of discourses, in which the punchline activates the non-salient interpretation, the salient serious interpretation is not completely disregarded. But it seems that, in this case, the serious message 
is conveyed in a humorous tone. Thus, humorous and non-humorous interpretations are simultaneously activated.

Example 8

Fey: apparently I'm only the third woman to ever receive this award/ and I'm so honoured to be numbered with Lily Tomlin and Whoopee Goldberg/ but I do hope that women are achieving at a rate these days that we can stop counting what number they are at things

Audience: [APPLAUSE]

Fey:

Audience: APPLAUSE

Fey: I was the first female head writer at Saturday Night Live/ and yes/ I was only the second woman ever to be pregnant while on the show// and now tonight I am the third female recipient of this prize $\downarrow$ I would love to be the fourth woman to do something $\rightarrow$ but I just don't see myself married to Lorne

Audience: LAUGHTER

It is noticeable how the monologist uses humor not only for amusing the audience, but also for raising awareness about certain controversial topics such as the gender inequality, rape, violence. The absurdity of the actual reality is the main reason why people chuckle, even when the topics should not be laughable. All in all, we have seen how female stand-up comedians have in their hands the power to defy or embrace gendered clichés and expectations for their own purposes.

\section{Conclusion}

This analysis has allowed a focus on both the macro-level, contextually situated nature of gender and its construction at a micro-level in interaction with the public. We have aimed to stress the importance of examining spoken planned discourse data for Cognitive Linguistics and we have also demonstrated how interactional approaches to data analysis allow mental conceptualizations to be researched as discursive resources. Moreover, methods of analysis developed in Conversation Analysis, discourse analysis and interactional sociolinguistics have contributed to this detailed examination of the humorous sequences in Stand-up.

We have attempted to analyze the way female comics subvert genderbased behavioral norms and construct alternative identities through their humorous discourse. Results illustrate cutting edge research in humor language and gender studies. In fact, humor has been proved to be an ideal gendered device to get a point across effectively, its rhetorical function along with the jokey tone help transmit the message in an effective way. Our qualitative analysis has examined how gender stereotypes may be deconstructed through humor and we have also explored ways in which women enact their gender identities by telling self-deprecating humorous anecdotes, parodying men's power and questioning heteronormative norms. In addition, after analyzing the comediennes' speech style, we could argue that masculinity and 
femininity are social categories that are constructed in speech. When they spoke as a ladies-like, they used prosodic markers such as intonation, paralinguistic features like speaking softly and non-verbal resources like feminine manners, smiling and nodding in order to mock that stereotypical behavior.

Humor facilitates friendly interaction and helps participants negotiate identity. Humor can be characterized as a gendered discourse resource on which both men and women regularly draw when negotiating their gender identities in interaction; Women and men deploy humor differently, just as those with more power or control in a particular interaction use humor differently than those who are one down. Researchers have noted significant differences in the characteristics of men's and women's self-targeted humor, and shown that women and men tell different kinds of stories illustrating different types of humor

In short, seeing gender as a dynamic social construct, our results show that that the comediennes emphasize some of its treats depending on the humor effects she wants to achieve. Humor is a sociopragmatic device available to be harnessed for subverting expectations about feminine behavior and labels in planned discourse. Their hilarious satire takes aim at issues like parenthood, gender inequality, or sexual double standards and they manage to raise awareness about these problems in the audience. However, notwithstanding this positive effect, we may argue that humor a doubleedged sword. Our data show that this type of discourse also reinforces negative gender clichés and stereotypes.

We have seen in all these examples a discussion on some of the major issues of the patriarchal structure and an intention to reform it by making the audience think while still laughing. Women are claiming for equality and a share of the power, power to decide by their own, power to have their own voice and power to take part in the world's organization. These comedians push the audience to think beyond the constraints of fixed social identities and embrace a world where there is place for every gender identity. But, in order to redefine gender roles for both sexes, men have to be involved in this movement. It would be interesting to observe if male comedians also talk about this issues in their performances.

Furthermore, self-deprecation is a common tool used for humor by both genders. We have demonstrated that female comedians use self-disparaging humor not to be accepted as comedians -as it happened some time ago- but it functions as a social group boundary strategy with the female sector of the audience to protect the positive face of the speaker and also to despise the fashionable norms and sex roles. But because of the small size of the sample used in the paper, these reflections on the use of humor for constructing gender identities are only the first step of a future broader study.

In further research, it would be interesting to examine the different humorous speech styles by which men and women perform their identity on stage. "What counts as a good laugh varies along gender lines" (Coates, 
2014), so we are convinced that comparing male and female comedians in this area would be an interesting addition to this study. It has been argued that men are more into the so-called "canned jokes" and women usually bring forward personal anecdotes and funny stories about themselves, in other words, self-deprecatory humor style. However, to my mind, more information is needed about the register, the language and the discourse strategies employed without limiting the analysis to a binary comparison of both genders. Researchers should broad the scope of their investigations and analyze gendered patterns of humor production from a wider perspective, taking into consideration other non-normative forms of gender. Additionally, much of the research done so far has been limited to English-speaking contexts, but in order to make broader claims, these studies need to be contrasted with other cultures and comedians from other parts of the world.

\section{REFERENCES}

ATTARDO, S. (1994): Linguistic Theories of Humour (Vol. 1), Walter de Gruyter.

BANKS, M., \& SWIFT, A. (1987): The Joke's on Us: Women in Comedy from Music Hall to the Present Day. Unwin Hyman.

BIANCO, M. (2015): "Comedians Are Leading the Feminist Movement--And Here's What That Says About Us," mic.com, http:/ / mic.com/articles / 113262/comedians-areleading-the-feminist-movement-and-here-s-what-thatsays-about-us\#.ebLllcvyG. (Retrieved on $15^{\text {th }}$ September 2017)

BUTLER, J. (1990): Gender trouble: Feminism and the subversion of identity. New York: Routledge.

BUTLER, J. (1993): "Critically queer", GLQ: A journal of Lesbian and Gay Studies, 1(1), 1732.

CAMERON, D. (1990). Discourses of desire: liberals, feminists, and the politics of pornography in the 1980s, American Literary History, 2(4), pp. 784-798.

CAMERON, D. (1995): Rethinking language and gender studies: some issues for the 1990s, Language and gender: interdisciplinary perspectives. London: Longman, pp. 31-44.

CAMERON, D. (1997): "Performing gender identity: Young men's talk and the construction of heterosexual masculinity", In Johnson, S., \& Meinhof, U. (eds): Language and masculinity, 47- 65. Oxford: Blackwell.

CAMERON, D. (2009): "Theoretical issues for the study of gender and spoken interaction", In Pichler, P., \& E. M. Eppler: Gender and spoken interaction, pp. 1-17. London: Palgrave Macmillan.

CAMERON, D. \& KULICK D. (2003): Language and sexuality. Cambridge: Cambridge University Press.

COATES, J. (1993): Women, Men and Language. Harlow: Longman.

COATES, J. (1997): "Competing discourses of femininity", In Communicating gender in context, edited by Helga Kotthoff and Ruth Wodak, 285-314. Amsterdam: John Benjamins.

COATES, J. (1999): "Women behaving badly: Female speakers backstage", Journal of Sociolinguistics 3 (1), pp. 65-80. 
COATES, J. (2003): Men talk: Stories in the making of masculinities. Oxford: Blackwell.

COATES, J. (2007): "Talk in a play frame: More on laughter and intimacy", Journal of Pragmatics, 39(1), pp. 29-49.

COATES, J. (2014): "Gender and humor in everyday conversation", Gender and humor: Interdisciplinary and international perspectives, 145-166.

CHIARO, D., \& BACCOLINI, R (eds.). (2014): Gender and humor: Interdisciplinary and international perspectives. Routledge.

CRAWFORD, M. \& GRESSLEY, D. (1991): Creativity, caring and context - Women's and men's accounts of humor preferences and practices. Psychology of Women Quarterly 15 (2): 217 231.

CRAWFORD, M. (1995): Talking difference: On gender and language (Vol. 7). London: Sage.

CRAWFORD, M. (2003): "Gender and humor in social context", Journal of pragmatics, 35(9), pp. 1413-1430.

ECKERT, P. \& MCCONNELL-GINET, S. (2003): Language and gender. Cambridge: Cambridge University Press.

ECKERT, P. \& MCCONNELL-GINET, S. (2007): "Putting communities of practice in their place", Gender and Language 1 (1), pp. 27-37.

GAL, S. (1995): "Language, gender, and power", Gender articulated: Language and the socially constructed self, pp. 169-182

GIORA, R. (2003): On our mind: Salience, context, and figurative language. Oxford University Press.

GLASS, L. (1993): He says, she says: Closing the communication gap between the sexes. New York, NY: Pedigree.
HALBERSTAM, J. (1998): Female masculinity. Duke University Press.

HARRIS, R. J. \& COOK, C. A. (1994): "Attributions about spouse abuse: It matters who the batterers and victims are", Sex Roles, 30(7), 553-565.

HAY, J. (2001): "The pragmatics of humor support", Humor: The International Journal of Humor Research 14, 55-82.

HOLMES, J. (2006). "Sharing a laugh: Pragmatic aspects of humor and gender in the workplace", Journal of pragmatics, 38(1), 26-50.

HOLMES, J. \& MARRA, M (eds.). (2010). Femininity, feminism and gendered discourse: A selected and edited collection of papers from the fifth international language and gender association conference (IGALA5). Cambridge Scholars Publishing.

HOLMES J., \& SCHNURR, S. (2014): "Funny, Feminine, and Flirtatious. Gendered Discourse Norms at Work", Chiaro, D. \& R. Baccolini (eds). Gender and Humor, pp. 165-181

HOLMES, J., \& KING, B. W. (2017): "Gender and sociopragmatics", Routledge handbook of pragmatics. London, England: Routledge.

JENKINS, M. (1985): "What's so funny?: Joking among women", In: S. Bremner, N. Caskey and B. Moonwomon, ed., Proceedings of the first Berkeley Women and Language Conference, pp. 135-151. Berkeley, CA: Women and Language Group.

KITZINGER, C. (2007). "Is' woman'always relevantly gendered?", Gender and Language, 1(1), pp. 39-49. 
KREFTING, R. (1978): All Joking Aside. Baltimore, MD: John Hopkins University Press.

LINARES BERNABÉU, E. (2020): “El estilo de habla en el discurso directo como estrategia para la construcción del género en el monólogo humorístico", Revista Signos, 53(102), pp. 123-143

LOCKYER, S. (2011): From toothpick legs to dropping vaginas: Gender and sexuality in Joan Rivers' stand-up comedy performance. Comedy Studies, 2(2), pp. 113-123.

MALTZ, D. N., \& BORKER, R. A. (1982): "A cultural approach to male-female miscommunication", A cultural approach to interpersonal communication: Essential readings, pp.168-185.

MARTIN, R. A., PUHLIK-DORIS, P., LARSEN, G., GRAY, J. \& WEIR, K. (2003): "Individual differences in uses of humor and their relation to psychological well-being: Development of the Humor Styles Questionnaire", Journal of research in personality, 37(1), pp. 48-75.

MARTIN, R. (2007): The psychology of humour: An integrative approach. Burlington, MA: Elsevier.

MEYERHOFF, M. (1996): "Dealing with gender identity as a sociolinguistic variable", In V.L. Bergvall, J.M. Bing, and A.F. Freed (eds) Language and Gender Research: Rethinking Theory and Practice (pp. 225-52). London and New York: Longman.

MEYERHOFF, M., \& NIEDZIELSKI, N. (1994): "Resistance to Creolization: An intergroup account", Language and Communication 14 (4), 313-30.
MINTZ, L. E. (1985): "Standup Comedy as Social and Cultural Mediation." American Quarterly. 37(1), pp. 71-80

MULLANY, L. (2007): Gendered discourse in the professional workplace. Springer.

OCHS, E. (1992): "Indexing gender", In A. Duranti and C. Goodwin (eds) Rethinking context: Language as an interactive phenomenon, 11, pp. 335-358.

RASKIN, V. (1985): Semantic mechanisms of humour. Boston: Reidel

RODGER, G. (2004): "Drag, camp and gender subversion in the music and videos of Annie Lennox", Popular Music, 23(1), pp. 17-29.

RUIZ GURILLO, L. (2012): La lingüistica del humor en español. Arco Libros.

RUIZ GURILLO, L. (2014): "Infiriendo el humor. Un modelo de análisis para el español", Círculo de Linqüistica Aplicada a la Comunicación, vol. 59, p. 148-162.

RUIZ GURILLO, L. (2019a): Humor de género: del texto a la identidad en español. Iberoamericana Editorial Vervuert

RUIZ GURILLO, L. (2019b). "Performing gender through stand-up comedy in Spanish", The European Journal of Humour Research, 7(2), pp. 67-86.

RUSSELL, D. (2002): "Self-deprecatory humour and the female comic", thirdspace: a journal of feminist theory \& culture, 2(1).

SCHEGLOFF, E.A. (1992): "Introduction", in H. Sacks, Lectures on Conversation (Vols I and II, G. Jefferson, Ed.). Oxford: Blackwell.

SCHEGLOFF, E. A. (1997). Whose text? Whose context? Discourse \& society, 8(2), pp. 165-187.

STOKOE, E. H. \& SMITHSON, J. (2001): "Making gender relevant: Conversation analysis 
and gender categories in interaction", Discourse \& Society, 12(2), pp. 217-244.

STOKOE, E. (2008): "Dispreferred actions and other interactional breaches as devices for occasioning audience laughter in television sitcoms", Social Semiotics, 18, pp. 289-307.

TANNEN, D. (1992): "How men and women use language differently in their lives and in the classroom", The Education Digest, 57(6), 3.

TIMOFEEVA TIMOFEEV, L. (2014): "El humor verbal en niños de Educación Primaria: desarrollo de la conciencia metapragmática", Feminismo/s, 24, pp. 195-219.
VEALE, T., KURT F. \& GEERT BRONE (2006): "The cognitive mechanisms of adversarial humor", Humor, 19, pp. 305-40.

YUS, F. (2002): "Stand-up comedy and cultural spread: The case of sex roles", Babel AFIAL, 10, pp. 245-292.

YUS, F. (2016): Humour and Relevance, Vol. 4, John Benjamins Publishing company.

WILLIS, K. (2003): Making sense of humor: some pragmatic and political aspects (PhD dissertation, London Metropolitan University) 